\title{
Fra spyd til helikopter - geoelektrikkens udvikling fra idé til virkelighed
}

Af hydrogeolog Johan Linderberg, Odense Vandselskab as

De geologiske kortlægningsmetoder er løbende blevet udviklet fra den DC-geoelektriske målemetode i 1950'erne til slæbegeoelektrik i slutningen af 1980'erne. Senest har den luftbårne SkyTEM vundet indpas.

I forbindelse med store lineære anlægsprojekter som banelinier og motorvejsbyggeri er det nødvendigt med geotekniske undersøgelser af undergrunden. Da det er meget kostbart at udføre et tæt net af boringer i fx områder med stor variation i de geologiske formationer, har der været et behov for en økonomisk metodik til at identificere de problematiske områder.

I Danmark begyndte man i midten af 1950'erne at anvende den traditionelle DC-geoelektriske målemetode med spyd i råstofkortlægning og grundvandsundersøgelser. Metoden var og er udmærket til at kortlægge de formationsmæssige forhold, men hæmmet af et stort tidsforbrug, da det tager tid at flytte opstillingen af spyd fra målelokalitet til målelokalitet, hvilket medfører en meget begrænset dagsproduktion $\mathrm{i}$ forhold til fladekortlægningen.

\section{Slæbegeoelektrikkens fødsel}

I 1988 satte en henvendelse fra Vejdirektoratet imidlertid skub i udviklingen. Myndigheden ønskede at kortlægge motorvejstraceen rundt om Århus fra syd til nord, og i den forbindelse fik lektor Kurt Sørensen fra
Geologisk Institut i Århus en idé til, hvordan man kunne foretage målingerne uden brug af de jordspyd, som kendetegner den traditionelle DC-geolektriske metode.

Hans idé gik ud på at trække et langt kabel med en række stålelektroder og et computerstyret geoelektrikapparat monteret på et lille køretøj, så man kunne få en række tætliggende målepunkter kontinuert langs profillinien. Kurt Sørensens første prototype af slæbegeolektrikmaskinen, som i dag er kendt som PACES-metoden (Pulled Array Continuous Electrical Sounding, red.), var et 3-kanals slæb, som målte værdier for $\mathrm{a}=$ 5, 10 og 15 meter.

Da metoden var nyudviklet, blev den i første omgang testet på en forsøgsstrækning ved omfartsmotorvejen ved Århus, hvor man også målte strækningen med traditionel spydgeoelektrik for at sammenligne de to datasæt. Testkørslen blev gennemført med stor succes, og den første reelle opgave blev at kortlægge motorvejstraceen.

Siden blev metoden indført som afløsning for den traditionelle spydkortlægning, i forbindelse med at Århus Amt skulle kortlægge amtets grundvandsressourcer, og et samarbejde mellem Geologisk institut, Århus Kommunale Værker og Århus Amts Grundvandsafdeling førte til en videreudvikling af slæbegeoelektrikken, så den kunne dække måleafstande: a=10, 20 og 30 meter.

Den nye metode vakte så stor begejstring, at udstyret efterfølgende blev gjort kommercielt tilgængeligt og anvendt ved alle nye motorvejsanlæg samt et stort antal amtslige grundvandskortlægninger op gennem 1990'erne.

\section{TEM til lands og i luften}

Da traditionelle DC-målinger kommer til kort, når det drejer sig om dybereliggende strukturer, besluttede Kurt Sørensen at arbejde videre med udviklingen af de geoelektriske metoder og deres anvendelse. I den forbindelse udviklede han i 1990'erne en metode til at overføre den transient elektromagnetiske metode (TEM) til en lignende fremgangsmåde som slæbegeoelektrik. Størrelsen på spolekonfigurationen er imidlertid meget stor, og han besluttede sig derfor for at overføre idéen til en luftbåren konfiguration, da TEM-metoden ikke er direkte afhængig af jordkontakt.

Resultatet blev udviklingen af udstyr og software til den nye og avancerede fladekortlægningsmetode, SkyTEM, der blev introduceret $\mathrm{i}$ det nye årtusinde.

\section{Valuta for pengene}

I de seneste år er SkyTEM-metoden blevet brugt flittigt af amterne til den landsdækkende gebyrfinansierede indsatskortlægning. Efter amternes nedlæggelse fortsættes kortlægningen af Statens Miljøcentre, og her anvendes de geoelektriske metoder som en fast bestanddel.

Udviklingen af de traditionelle geoelektriske metoder til nye, effektive og rationelle målemetoder har haft stor indflydelse på kortlægningsomfanget og medvirket til væsentligt bedre måleresultater til gavn for ressourceforvaltningen (Stat, kommuner og vandforsyninger), således at planlægning, udbygning og beskyttelse af grundvandet kan foretages med stor sikkerhed for optimering af anvendelsen af de økonomiske midler, som er til rådighed. 